\title{
Comparison of Fastening Methods of Military Vehicles on Railway Freight Wagons Using Fastening Straps
}

\author{
Martin VLKOVSKÝ ${ }^{1}$
}

\begin{abstract}
The paper identifies possible ways of fastening military vehicles on rail freight wagons using textile fastening straps and then compares particular methods. The comparison includes, besides used methods-diagonal lashing and V-shape diagonal lashing, the previously used method of lashing-slope lashing, which is currently not allowed to use. To calculate the inertia forces affecting the cargo, respectively the fastening straps, appropriate methods in accordance with EN 12195-1 have been chosen. In the discussion part, recommendations in relation to the fastening of military vehicles on rail freight wagons are introduced.
\end{abstract}

Keywords: fastening, fastening straps, inertia forces, railway freight wagons

\section{Introduction}

Railway transport represents an important mode of transport for the Army of the Czech Republic. On the one hand railway transport is not so suitable for transportation of small amount (number) of military vehicles and material for a short distance, on the other hand it is quite effective for transportation of large amount (number) of military vehicles for medium and long distance. The paper is focused on railway transport of ground military vehicles with emphasis on transport selected tracked vehicles. When transporting, in any mode of transport, inertia forces act on the carried cargo. Although the exact size of forces is unknown before the start of transport, it can be assumed from the empirically determined acceleration coefficients that are part of the relevant standards (e.g. EN 12195-1). [1] In case of military transfers and transports, the ground military vehicles must be fastened taking into consideration the assumed size of the inertia forces. It is necessary to choose the method of fastening taking into account the type and weight of the ground military vehicles and the type of railway freight wagon. If the cargo-ground military vehicle is incorrectly or inadequately fastened, during the railway transport it may shift, fall, etc. which can cause damage to the fastening material, cargo (ground military vehicles) or railway freight wagon. In extreme cases, after the railway transport itself, the incorrect unloading may result in injuries to the unloading group.

Major, Ph.D., Assistant Professor, University of Defence, Faculty of Military Leadership, Department of Logistics; e-mail: martin.vlkovsky@unob.cz 


\section{Basic Principles of the Fastening of Ground Military Vehicles to the Railway Freight Wagons}

Freight fastening, ground military vehicles in this case, is being proceeded in accordance with the provision Allied Movement Publication STANAG 2468 CSS (Edition 2): Technical Aspects of the Transport of Military Materials by Railroad AMOVP-4(A), [2] eventually Loading guidelines UIC - International Railway Union, [3] Volume 2 - Goods, eventually with Guideline of CDC for provisioning of military rail transport to the code D33. [4]

According to the previously mentioned regulation, it is possible to use the following material for fastening ground military vehicles: [2] [3] [4]

- wedges with steel thorns;

- wooden wedges;

- underlay wedges;

- locking wood;

- binding wires;

- wheel stops;

- fastening straps.

This article will focus on one of the most frequently used fasteners according to the conditions of The Army of the Czech Republic - a fastening strap. A critical value for fastening straps is the Lashing Capacity (LC), which sets the maximal load - pulling force, which is guaranteed by the producer and to which the fastening strap is dimensioned.

The value of the Lashing Capacity cannot be confused with the Breaking Force (BF), which shows the power during a rupture, for which the fastening strap is designed (EN 121952). [5] The producers ensure, for safety reasons, sufficient difference between LC and BF, that in case of improper use of the fastening strap, meaning its overloading, will not end up in immediate rupture. During the use of a fastening strap for heavier freight or generally during the effect of stronger than assumed inertial forces, the lifetime of the individual strap components is reduced. Responsibility for any damage is an important aspect, that is why the producer guarantees possible tension only until the moment, when:

$$
\text { Fx,y,z } \leq \mathrm{LC}
$$

- where $F x, y, z$ represents a general list of inertia forces acting in axes (x, y and z).

In accordance with source [2] and [3], ground military vehicles fasten differently on the front, respectively on the rear of the vehicle. From the front of the ground military vehicle, the straps are guided diagonally in the shape of the letter $V$, from the rear of the ground military vehicle, they are lead diagonally by crossing. (Figure 1) [6] 


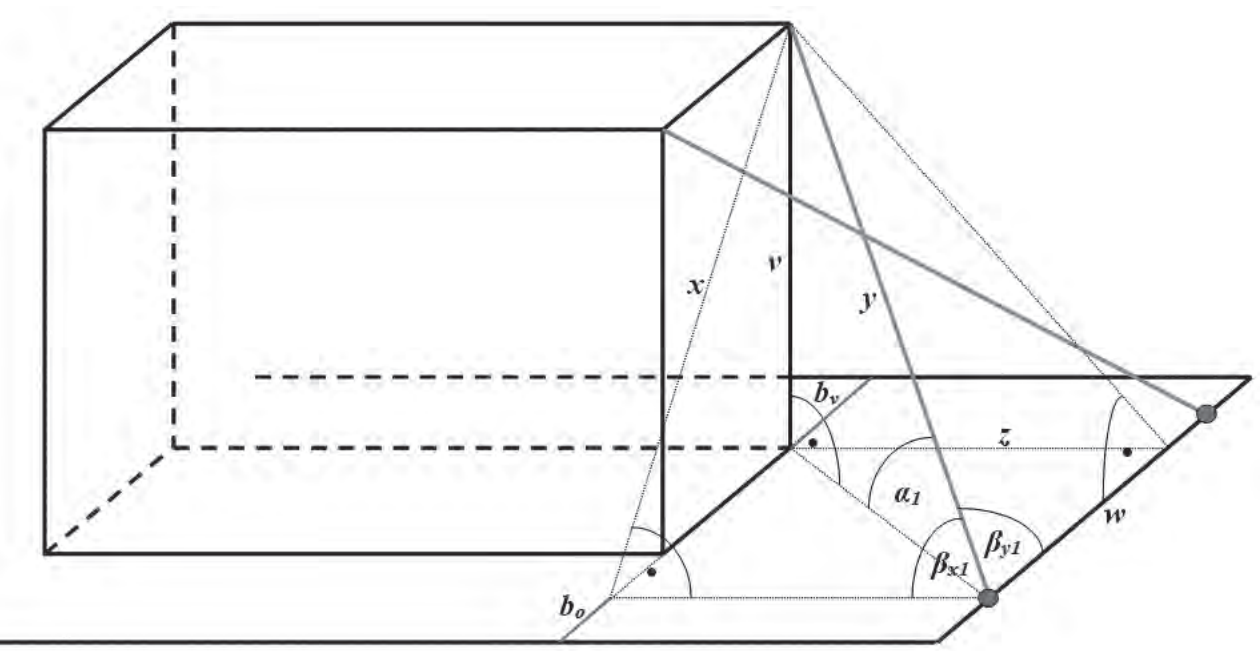

Figure 1. Fastening model - diagonally by crossing of the ground military vehicle on a railway freight wagon. [Edited by the author.]

The anchor points on the ground military vehicles and their distance from the anchor points (steel holes) of the freight wagon are decisive for fixation in this way. The provision [5] specifies the angle, which should be used to fasten the fastening strap with the imaginary surface of the ground military vehicle, to be $30^{\circ}$. (Figure 2 .) In real conditions, it is possible to choose any anchor point on the railway freight wagon, which has its angle as close as possible to the required $30^{\circ}$.

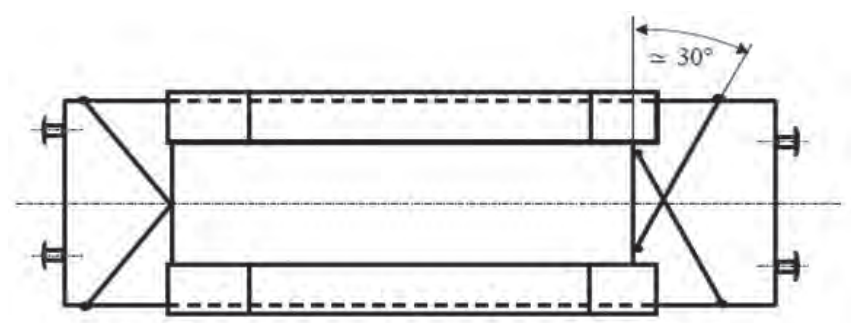

Figure 2. Fastening of ground military vehicles on a railway freight wagon using fastening straps. [2]

\section{Fastening Model of Infantry Combat Vehicle}

The key factor in the fastening of required ground military vehicle is the correct choice of a railway freight wagon, which matches that military vehicle in its length, load capacity and positions of the anchor points. Especially the above mentioned angle (Figure 2) provides sufficient ability to fasten a military vehicle. This requirement is especially much more significant to military vehicles with a higher weight, such as tracked vehicles, for which 
it is assumed to have higher values of inertial forces (Fx, y, z). Available freight wagon length and ability to load the ground military vehicle on a railway freight wagon is analysed in the paper. [6] For the purposes of this paper, there will be discussed the parameters used in the following formula, which is based on EN 12195-1 standard: [1]

$$
F=m \cdot g \cdot \frac{\left(c_{x, y}-\mu \cdot f_{\mu} \cdot c_{z}\right)}{2 \cdot\left(\cos \alpha \cdot \cos \beta_{x, y}+\mu \cdot f_{\mu} \cdot \sin \alpha\right)}[N]
$$

- where $F$ is the searched inertial force (inertial forces), which can be expected during the transportation by parameters of the ground military vehicle, railway freight wagon, railway track and other conditions (e.g. weather conditions), $m$ means the weight of the cargo-ground military vehicles, $g$ means gravitation acceleration, $c_{x, y, z}$ means the acceleration coefficient in the appropriate axes, $\mu$ means dynamic coefficient of friction, $f_{\mu}$ recalculating coefficient of friction, $\alpha, \beta_{x, y}$ represents the angles, which are held by the used fastening straps with appropriate surfaces. (Figure 1)

Model assumptions:

- the cargo is made of military fighting vehicle BVP-2, which is in service of the Army of the Czech Republic; (Table 1)

- four-axle railway freight wagon series Smmps 54 in technical interval 4728 (Table 2) is used for transport of BVP-2;

- BVP-2 is, on the railway freight wagon, centred both longitudinally and transversely in the axle of the railway freight wagon;

- for fastening there are used anchor points in the front and the rear part of the vehicle (on Figure 1 they are demonstrated by the top edges of the model block);

- for fastening normally used fastening straps with LC $=5,000 \mathrm{daN}$ or $10,000 \mathrm{daN}$ are used.

To determine the searched inertial forces, respectively the restraining force of the lashing straps, the values from Table 3 and B.1 in source [1] should be used; to determine the size of relevant angles $(\alpha, \beta)$ the corresponding trigonometric functions and the Pythagoras theorem are to be used.

Basic input data are derived from the Tactical-Technical Data of the transported cargo (BVP-2) and the used railway freight wagon (Smmps 54 at the Technical Interval 4728). The selected data is summarized in Tables 1 and 2.

Table 1. Basic technical parameters of BVP-2 are used in the calculation. [7] [8]

\begin{tabular}{|l|r|c|l|}
\hline \multicolumn{1}{|c|}{ Parameter } & \multicolumn{1}{c|}{ Value } & Unit & Note \\
\hline Weight $(\mathrm{m})$ & 14,300 & $\mathrm{~kg}$ & \\
\hline Width & 2,700 & $\mathrm{~mm}$ & \\
\hline Height $(\mathrm{v})$ & 1,600 & $\mathrm{~mm}$ & Lashing point at the same height. \\
\hline Length & 6,720 & $\mathrm{~mm}$ & \\
\hline
\end{tabular}




\begin{tabular}{|c|l|l|l|}
\hline Parameter & Value & Unit & Note \\
\hline Distance 1 (bv) & 350 & $\mathrm{~mm}$ & $\begin{array}{l}\text { The distance of the fastening points on the vehicle from } \\
\text { the side edge of the railway freight wagon. }\end{array}$ \\
\hline Distance 2 (z) & 3,000 & $\mathrm{~mm}$ & $\begin{array}{l}\text { The distance of the fastening points on the vehicle } \\
\text { from the surface where the anchor points are located on } \\
\text { the railway freight wagon. }\end{array}$ \\
\hline
\end{tabular}

Table 2. Basic technical parameters of the Smmps 54 railway wagon in the technical interval 4728 are used in the calculation. [8]

\begin{tabular}{|l|c|l|l|}
\hline \multicolumn{1}{|c|}{ Parameter } & \multicolumn{1}{|c|}{ Value } & Unit & Note \\
\hline Loading length & 14,000 & $\mathrm{~mm}$ & \\
\hline Loading width & 3,100 & $\mathrm{~mm}$ & \\
\hline Wagon width (w) & 3,100 & $\mathrm{~mm}$ & \\
\hline Distance 3 (bo) & 200 & $\mathrm{~mm}$ & $\begin{array}{l}\text { The distance of the fastening points from the side } \\
\text { edge of the railway freight wagon. }\end{array}$ \\
\hline
\end{tabular}

The acceleration coefficients and friction factors from Table 3 are also used for the calculation. The values of the acceleration coefficients apply to railway transport. Interestingly, the values of the acceleration coefficients presented in The Regulation concerning the International Carriage of Dangerous Goods by Rail (RID), which is the connection C to The Convention concerning International Carriage by Rail, are higher.

For the friction factor, two values are used (Table 3) which demonstrate the difference between track and wheel vehicles. However, the calculation abstracts from the larger contact area in case of tracked vehicles. This could reduce the difference between calculated inertia forces for track and wheeled vehicles. The value of friction factor 0.6 is used only to model the illustration difference in access to different types of vehicles (track versus wheel).

If necessary, special cover can be used on straps or special anti-skid surfaces on the transport vehicle. However, the use of anti-skid surfaces is not applied very frequently in railway transport (in particular railway freight wagons). Frequent use of anti-skid surface is used in road transport. In combined transport there is the possibility of using removable transport platforms or storage containers, where the type of floor is variable and the customer requirements (in this case the army) are met.

Table 3. Values for calculating inertia forces. [1]

\begin{tabular}{|l|c|c|}
\hline \multicolumn{1}{|c|}{ Parameter } & Value & Unit \\
\hline Gravitational acceleration $(\mathrm{g})$ & 9.81 & $\mathrm{~m} \times \mathrm{s}^{-2}$ \\
\hline Coefficient of longitudinal acceleration (cx) & 1.0 & - \\
\hline Transverse acceleration coefficient $(\mathrm{cy})$ & 0.5 & - \\
\hline Coefficient of vertical acceleration $(\mathrm{cz})$ & 1.0 & - \\
\hline Conversion factor for friction $(\mathrm{f} \mu)$ & 0.75 & - \\
\hline Friction factor - tracked vehicles $(\mu \mathrm{t})$ & 0.3 & - \\
\hline Friction factor - wheeled vehicles $(\mu \mathrm{w})$ & 0.6 & - \\
\hline
\end{tabular}


Finally, Table 4 summarizes the sizes of angles, which are required to calculate the inertia forces. For the first set of angles $(\alpha 1, \beta x 1, \beta y 1)$ Figure 1 can be used, other schemes for further types of fastening (slope lashing and V-shape diagonal lashing) would be analogous. Angle calculations are based on Tables 1 and 2 .

Table 4. Angle sizes and their specifications. [Edited by the author.]

\begin{tabular}{|l|l|c|c|}
\hline Sign & \multicolumn{1}{|c|}{ Specification } & Angle size & Unit \\
\hline$\alpha_{1}$ & Angle for crossed diagonal lashing & 22.12 & $\circ$ \\
\hline$\alpha_{2}$ & Angle for slope lashing & 28.04 & $\circ$ \\
\hline$\alpha_{3}$ & Angle for V-shape diagonal lashing & 25.94 & $\circ$ \\
\hline$\beta_{\mathrm{x} 1}$ & Longitudinal direction - angle for crossed diagonal lashing & 45.10 & $\circ$ \\
\hline$\beta_{\mathrm{x} 2}$ & Longitudinal direction - angle for slope lashing & 28.18 & $\circ$ \\
\hline$\beta_{\mathrm{x} 3}$ & Longitudinal direction - angle for V-shape diagonal lashing & 34.91 & $\circ$ \\
\hline$\beta_{\mathrm{y} 1}$ & Transverse direction - angle for crossed diagonal lashing & 53.13 & $\circ$ \\
\hline$\beta_{\mathrm{y} 2}$ & Transverse direction - angle for slope lashing & 87.47 & $\circ$ \\
\hline$\beta_{\mathrm{y} 3}$ & Transverse direction - angle for V-shape diagonal lashing & 68.34 & $\circ$ \\
\hline
\end{tabular}

The size of the individual angles fundamentally affects the resulting inertia force that acts on the strap and is determined by the type of fastening. The corresponding type of fastening corresponds to the formula (2) resulting from EN 12195-1. Different influence of the angles on the final calculation is demonstrated, for example, by a contribution in the proceedings. [9]

Using the input data from Tables 3 and 4, the required sizes of inertia forces are calculated, which must correspond to the permissible load-carrying capacity-traction force (LC) of the used fastening straps. The inertia forces are calculated for the $\mathrm{x}$ and $\mathrm{y}$ axes, for each of the three fastening methods and for two different sizes of friction factor (for $\mu t=0.3$ and model value for $\mu \mathrm{w}=0.6$ ). The values of inertial forces are summarized in Table 5 , showing the size of the inertial forces, i.e. regardless of their direction (sign).

It can be seen from Table 5, that there are large differences between sizes of inertia forces in individual axes using different fastening methods. Red highlighted is the prohibited method of fastening - slope lashing, which is the cause of the prohibition of using the inappropriateness of protecting the cargo against the undesirable effects of transverse inertial forces. In Table 5 it is the force F2y $=13.327$ daN, which significantly exceeds the value of the commonly used fastening strap with $\mathrm{LC}=10,000 \mathrm{daN}$. In general, it is clear that the lashing slope is a very appropriate way of fixing against the effects of longitudinal inertial forces (F2x), but very unsuitable against $y$-axis forces (F2y). From the values of the other inertial forces that are calculated for the remaining two fastening methods, respective two axes (x and y), it is obvious that inertia forces are between 3,011-7,359 daN. For fastening BVP-2 to the relevant railway freight wagon, it is necessary to use fastening straps with $\mathrm{LC}=10,000 \mathrm{daN}$. The straps with LC $=5,000$ daN would not have sufficient $\mathrm{x}$-axis lashing capacity for both methods of fastening (cross-diagonal lashing and V-shape diagonal lashing). The sizes of the inertia forces found at the same time demonstrate the advantage of using the combination of the two fastening 
methods, because one is more suitable for fastening ground military vehicles in the longitudinal direction and the second in the transverse direction.

Table 5. Sizes of the searched inertia forces. [Edited by the author.]

\begin{tabular}{|l|l|c|c|c|}
\hline Sign & Specification & Value for $\mu \mathrm{t}$ & Value for $\mu \mathrm{w}$ & Unit \\
\hline $\mathrm{F}_{1 \mathrm{x}}$ & Crossed diagonal lashing (x axis) & 7,359 & 4,685 & $\mathrm{daN}$ \\
\hline $\mathrm{F}_{2 \mathrm{x}}$ & Slope lashing (x axis) & 6,151 & 3,899 & $\mathrm{daN}$ \\
\hline $\mathrm{F}_{3 \mathrm{x}}$ & V-shape diagonal lashing (x axis) & 6,503 & 4,129 & $\mathrm{daN}$ \\
\hline $\mathrm{F}_{1 \mathrm{y}}$ & Crossed diagonal lashing (y axis) & 3,011 & 484 & $\mathrm{daN}$ \\
\hline $\mathrm{F}_{2 \mathrm{y}}$ & Slope lashing (y axis) & 13,327 & 1,400 & $\mathrm{daN}$ \\
\hline $\mathrm{F}_{3 \mathrm{y}}$ & V-shape diagonal lashing (y axis) & 4,482 & 663 & $\mathrm{daN}$ \\
\hline
\end{tabular}

The theoretical model, which evaluates the hypothetical possibility, where BVP-2 is a wheeled vehicle with the same values but with a friction factor of $(\mu \mathrm{w})$, is mentioned in the next column in Table 5. Due to its doubled friction factor value ( $\mu \mathrm{w}=2 \mu \mathrm{t}$ ) the inertial forces are significantly smaller in both axes than in the real tracked version of BVP-2. In the y axis, the inertial forces (F1y, F3y) are insignificant, in the y axis they do not outreach 5,000 daN (F1x, F3x) and for that purpose it would be possible to fasten the model vehicle with no problems only with fastening straps with lashing capacity LC = 5,000 daN.

\section{Conclusion}

The submitted contribution demonstrates important knowledge of the basic parameters of the transportation right before the commencing of the transport. The basic inputs were mentioned in the formula (2), where the values are given by the cargo (its weight), norm (EN12195-1), contact surfaces between the transported vehicle and the railway freight wagon and the angles, which are held by the fastening straps with appropriate surfaces. Certain deficiencies are the normative values of the acceleration coefficients, which can be different (higher) values during the real transportation (see e.g. [10] [11] [12]).

The calculation of the transportation model points to the importance of using allowed ways of fastening and to the right choice of anchor points on the railway freight wagon. The right implementation of the mentioned activities ensures effectiveness and safe course of the railway transportation.

Subject of the following research will be verification and statistical evaluation of realvalued acceleration coefficients. Subject of the analysis will not be only transportation, but mainly the train composition, where it is possible to assume significant size of the inertial forces in the $\mathrm{x}$ axis. Important factor will be the consideration of the choice of the right railway freight wagon, which will allow not only the load of the ground military vehicle, but also its proper fastening. In this respect can be the compliance of the required angle of $30^{\circ}$ considered as one of the key factors, as Figure 2 implies. 
M. VLKOVSKÝ: Comparison of Fastening Methods of Military Vehicles...

\section{Acknowledgement}

The paper was written with the support of specific research project no. SV16-FVL-109VLK: "Optimization of Cargo Securing for Off-road Transportation with Emphasis on Transportation Safety" funded by the Ministry of Education, Youth and Sports.

\section{References}

[1] ČSN EN 12195-1. Zajištování břemen na silničních vozidlech - Bezpečnost. Část 1: Výpočet zajišt’ovacích sil. Praha: Úřad pro technickou normalizaci, metrologii a státní zkušebnictví, 2011.

[2] STANAG 2468 CSS (Edition 2). Technical Aspects of the Transport of Military Materials by Railroad - AMOVP-4(A). Brussels: NATO Standardization Agency, Military Committee Land Standardization Board, 2011.

[3] RIV - Př́lloha II. Nakládací směrnice 7.1-7.3, svazek 2. Paříž: Mezinárodní železniční unie, 2005.

[4] Č.j.: S 16766/2012-BEZ - Vnitřní předpis. D-33 Vojenské přepravy. Správa železniční dopravní cesty, 2012, 18.

[5] EN 12195-2. Prostředky pro zajištování břemen na silničních vozidlech - Bezpečnost. Část 2: Přivazovací popruhy ze syntetických vláken. Praha: Úřad pro technickou normalizaci, metrologii a státní zkušebnictví, 2003.

[6] REJZEK, M., VLKOVSKÝ, M., BINAR, T.: The Selection of Methods of Land Military Equipment Direct Lashing on Railway Goods Wagons and their Verification by Means of Calculation. Economics and Management, 3 (2012).

[7] BVP-2. Bojové vozidlo pěchoty. 2015. https://cs.wikipedia.org/wiki/BVP-2 (Downloaded: 13.03.2017)

[8] REJZEK, M., NEDBAL, J.: Vojenská přeprava po železnici III - železniční nákladní a osobní vozy využívané v Armádě České republiky. Brno: Univerzita obrany, 2011.

[9] VLKOVSKÝ, M., RAK, L., TAKSÁS, B.: Cargo Securing During Transportation - Using Extreme Values. In. The $23^{\text {rd }}$ International Conference The Knowledge-Based Organization: Applied Technical Sciences and Advanced Military Technologies. Sibiu: Nicolae Balcescu Land Forces Academy Publishing House, 2017, 142-147.

[10] VLKOVSKÝ, M. et al.: The Cargo Securing Based on European Standards and its Applicability in Off-road Transport Conditions. In. ICTTE Belgrade 2016 - Proceedings of Third International Conference on Traffic and Transport Engineering. Belgrade: Scientific Research Center Ltd. Belgrade, 2016, 603-607.

[11] VLKOVSKÝ, M., POCHOBRADSKÁ, K., FOLTIN, P.: Přeprava v terénu a zajištění nákladu. Crede Experto: transport, society, education, language, 2 (2016).

[12] VLKOVSKÝ, M., VLACHOVÁ, H.: Upevňování nákladu na vojenských nákladních vozidlech - Přepravní experiment. Crede Experto: transport, society, education, language, 4 (2016). 